\title{
Methods of expressing religious beliefs through sacred numbers in the architecture and sport of Zurkhaneh
}

\author{
Nima Deimary' \\ Mohammad Mohammadi"
}

\begin{abstract}
Ancient sports, dating to the size of the history of Mithraism, have undergone many changes throughout history and have been mixed with Sufism and Shiism. As a result of these developments, Zurkhaneh's building also has a distinct root in the Islamic era by preserving patterns of the ancient world. The structure and its components are based on beliefs and sentiments that have been exhibited in different shapes in the architecture of Zurkhaneh building throughout history, holding symbolic concepts like sacred numbers. As in other examples of Iranian architecture, it has played a major role in the formation of architecture and sports of Zurkhaneh. Examples like the octagonal Field of Zurkhaneh, which is a symbol of the eight gates of Paradise and commemorating the eighth Shiite Imam, and the dome is a symbol of unity. This research tries to investigate the effect of sacred numbers on formation of archery sports and Zurkhaneh architecture by using a descriptive and analytic approach and using library documents and resources.
\end{abstract}

Keywords: Iranian Architecture; Zurkhaneh; Sacred Numbers

' Department of Architecture, Faculty of Civil and Architecture, Malayer University, Malayer, Iran N.Deimary@malayeru.ac.ir

"Department of Physical Education, Faculty of Literature and Humanities, Malayer University, Malayer, Iran M.mohammadi@malayeru.ac.ir 


\section{Introduction}

The Iranian world, with its signs and symbols, is meaningful, a country that has been under war, and hard climate for centuries and these are the reasons why in architecture, literature, and even in daily talks and social relations traces of symbols can be found. Numbers play a special role among the various symbols and hybrids that make the Iranian world. Each number referred to a particular topic and transmitted concepts. In a world in which the sciences were not as discrete as today, each number has binary meanings: in music, myth, gods, science, and even architecture, and so the traditional Iranian world was formed, for example when speaking of the "number four" It refers to four axes of the world, four geographic directions, four weathers, and four pillars of the world. And that's why ancient temples like "Choghazanbil" had four gates and was built upon the four geographic directions. The four sided cube with the dome over it, adjoined the earth to the sky and made a path for the ascension of man from earth to heaven, and so the dome was the number one just like God. Zurkhaneh sports have a great influence on the formation of morality and pious personality of the athletes; in fact, the identity is composed of the types of exercise movements. The way of exercising with the instruments of Zurkhaneh is combined with epic and religious poetry. As Zurkhaneh's instruments, the traditional architecture and the presence of both ancient and contemporary epic and religious characters are complementary to each other, and this ancient sport has been seriously influenced by religious and socio-ethical issues from the beginning. .

After Islam, there are also some social and religious behaviors such as Sufism and mysticism, heroism, and Shi'ism, in which these effects also appear in the manifestation of this sport; in the way athletes dress up, places of sport, speeches of athletes, etc.. And in their deeds, which increases the Zurkhaneh's influence on the formation of national identity and leads to the formation of heroic identity (Deimary and Mohammadi, 2017) The attention to numbers and symbols in other civilizations also has deep roots. In the city of Uruk, in the ancient Sumerian civilization, Anu God of heaven was a goddess who was the owner of number one and in the trail he was associated with mathematics and commerce (Vaziri, 
2004). In ancient Greece, Plato considered nature as divine art and sought to discover the relationship between geometry and mathematics and numbers, to bring harmony to the world based on numbers. Pythagoras revealed the relationship between musical intervals, nature and numbers and believed, as the proportions of musical steps are measured by numbers, all objects of nature are made out of numbers, and so the universe. He believed that the number "one" is the symbol of " Point "," two " is" line ";" three " is ," surface "and" four ", shape. The proper number is "ten" because it is made up of the set of the above numbers, and therefore the planets must be ten, because our universe is proper (Dumper, 2007). After the advent of Islam, the attention to numbers and symbols appeared in architecture, from a Caravanserai like Zinuddin in Iran, which was constructed on the basis of numbers five and twelve, to the Sun Palace in Kalat Naderi and the school of Khan in Shiraz, based entirely on holy numbers. (Memarian, 2008). These symbols and holy numbers are much more visible in the architecture of a building like Zurkhaneh, which is famous for its special principles, hierarchies and complexity. For example, when the practice begins and the athlete "takes the stone", he uses symbolic words instead of numbers to count for the game. For example, the number seven is replaced by the seventh most beloved Imam of Baghdad; the number eight gives its place to the eighth Shiite Imam (Anwari, 2003).

In another example, while the athlete dresses up for the game, five candlesticks illuminated the symbol of five members of Mohammad -the prophet of Islam- family and read twelve words for disciples (Hodgson, 1999). Even the pattern of ancient costume design is based on holy numbers, from the seven margins, to pairs of cufflinks, which symbolize the two cedars in love, who are joined together. In such a space, Zurkhaneh's architecture also has symbolic elements, each of which, in addition to its material body, transmitted symbolic concepts, Zurkhaneh was often built to be out of sight, even a few meters below the surface of the ground to be down to earth, just like the way the athlete should be. Entering the Zurkhaneh occurs through a short droll, which points to every athlete to bend down and take a bow (Bahar, 1976.) The main playground of Zurkhaneh is covered with a dome that shines a light with its eight windows, becomes the main actor of the Zurkhaneh scene. The present research seeks to answer the question of whether sacred numbers, in addition to shaping the rituals, and sports actions in Zurkhaneh, have affected its architecture too? And 
if so, which of the elements of the architecture of Zurkhaneh have been influenced by holy numbers?

There is little scientific research on the recognition of the historical roots of the Zurkhaneh sports. As an example, Ebrahim Mokhtari has done a comprehensive research on ancient archeology in Iran on the history of Zurkhaneh Culture and its rituals (Mokhtari, 2002). The oldest book published in conjunction with Zurkhaneh belongs to Hussein Parto Bayizai, the "History of Ancient sports", which studies the status of Zurkhaneh's history in different centuries. The latest books, "Zurkhaneh in Iran" (Mehdi Abolhassani Naraghi), "Zurkhaneh for the acquisition of spirituality" (Seyyed Hussein Badr-Asa), "Zurkhaneh's fundamental building", Ali Valianpour (all of which are related to 1391; these are history books of Zurkhaneh and They have spoken about the ambient and explained the rituals and the manner in which they performed sports activities, and the spiritual virtues of the Zurkhaneh environment have been also expressed.

\section{Literature review}

In addition to rituals, similarities exist between ancient sport and Zoroastrian religion. Mithraism is one of the oldest Iranian religions, and though it has been replaced by the Zoroastrian religion after a while, but throughout the world, it found its supporters, Mithraists believed that Mithra was "the judge of the land of Iran." God of the covenant and the orderer of the truth, he is the guarantor of the relationship between human beings and peace and friendship. They believed that life in this world would not end, and the spirit would be "judged" and would go to heaven or hell (Dadvar, 2006). The wheel is a symbol of Mithra, and the wheel represents the sun's rays, and the wheel axis, is the center of the universe. The ring is a symbol of the wheel and a sign of knowledge, wisdom, clergy, covetousness, and the symbol of the reign. The circle is a symbol of equality, because all the points around it are the same (Dadvar, 2006).

According to legends, the goddess of Mithra, after his birth, was determined to measure his force and fought with the goddess of the sun and wrestled with him, the god of the sun fell on the ground, and then Mithra assisted him. And he rose up, and reached 
out his right hand toward the sun; and helped him up. Then he put a crown over the sun, and from then on, those two became close friends. In the Zurkhaneh, when an athlete falls while wrestling, the two wrestlers help each other up, and touch each others arms with the left hand, while shaking hands and, if a hatred arises, they must kiss each other and reconcile it (Bahar, 2011).

Zurkhaneh has been the source of good emotions and deeds in people, and they were trained to become a carrying person and fulfill their duties to their homeland and to their nation (Mohabbati, 2004).

Sufism, Dervishism, or mysticism is a kind of austerity based on the rules of conduct and on the basis of Shari 'a to cultivate the soul and the world's desires to gain the right and self-efficacy. In other words, Sufism is a way of inner revelation. (Sajjadi, 2001) Formation of Iranian Sufism is effected by the religion of Mani. In Manichaeism, excellence was solely due to worship and austerity and promotion in the spiritual classes and these concepts were associated with in Iranian Sufism (Nafisi: 1998). That's why seven degrees of conduct in Sufism in Iran are the same levels of spirituality as Manichaeism (Nafisi: 1998).

After the generalization of Shi'ism in Iran, as the Shiite cleric considered Imam Ali as the king if the athletes, since then, every sports in Zurkhaneh, was held under the name of Ali. Ali is the leader of the athletes, and he is called the king of men (Zarrin Kub, 1990).

After Islam, Zurkhaneh played an important role in restoring the Iranian national movement, as well as the resurrection of Iranian language, culture, and traditional rituals that has been prevalent in Iran since ancient times (Chartier, 2009). It was used both as a gymnasium and as a place for secret meetings, at the time the Iranians were training how to use the weapons, and the Arabs had banned such meetings (Muhabati, 2004).

Zurkhaneh Foundation is based on generosity and chivalry. In Zurkhaneh, ethical values such as honesty, humility and sacrifice are strengthened. In the ancient times, the heroes guarded the moral and spiritual values, because these values exist in sport, a local Zurkhaneh soon became a place for physical exercises and the training of warriors who fought against foreign enemies (Ensafpour, 1974). 
Zurkhaneh is a small social unit, traditionally built in the center of the most popular neighborhoods. Zurkhaneh is the heart of the neighborhood and the task of educating young men and athletes in the course of daily life (Ensafpour, 1974) (Fig. 1).

Some people believe that in addition to the ceremonies, the architecture of the Zurkhaneh also has roots in the Mithraist temples, where the ceremonies usually carried out in the caves. The caves representing the arc of the sky and the earth's ground. Near these natural temples, or within them, there should be a river or fountain. But in the cities where there were no caves, these temples built in the basement to resemble caves. The temple reached the surface with many steps; the temples did not have windows and looked like caves. Sometimes the stairs ended in a room where they prepared their followers for the ceremony, and then they entered the main courtyard of the temple. Inside, the arc of the temple was decorated like the sky, by drawing the sun and stars. In the inner space of the temple on two sides, there were two rows of platforms and between those rows, the rectangular scene, where the ceremony was performed and the audience watched the ceremonies on benches next to the platforms. At the end of the temple, there was a spectacular painting or sculpture of the Mithra, sacrificing a cow, alongside the entrance there was a fountain of water, symbolized by Anahita, the Iranian water goddess, on the opposite side, at the foot of the image of Mithra, There were two fireplaces that reminded the presence of Zorvan, the god of fire (Mohabbati, 2004). Zurkhaneh has a little light because the Mithraists believed that they should be placed in darkness to praise the light and brightness (Dadvar, 2006). Inside the Zurkhaneh, unlike the Temple of Mithra, there are no platforms and rectangular scene. The polygon or square shaped playground of the Zurkhaneh is surrounded by a platform all the way, but just like the temples of Mithra, beside the platform, is located at the foot of the bench wall, the viewers sit and watch the game. The polygon is drawn from the sixth and octagonal geometric shape, which is based on the grave of the third Shiite Imam, Hussein and on the eighth Imam, Reza. Some believes that scene of Zurkhaneh is an imitation of the basin that was built in the middle of the house courtyard, which makes it an important and sacred place for water. In another, the octagonal shape of the scene of the Zurkhaneh may also be derived from the eight-pointed star that 
was a popular shape in Islamic ornamentation. The scene is about $80 \mathrm{~cm}$ deep and about 7 $\mathrm{m}$ wide and is about $1.5 \mathrm{~m}$ away from people`s sitting place (Aghajani, 2012).

There are rooms around the scene to sit and watch or put on sports equipment or clothes. Therefore, the interior space of the Zurkhaneh is somewhat similar to Iranian old baths. The reason for the scene to be deep in the ground may have been that from the old days, people used to watch the wrestling game from above (Dadvar, 2006). Another narrative refers to the inspiration from Imam Hussein's pit of death in the plain of Karbala. Usually they filled the bottom of the scene floor to get springy with thistle and stubble, and they threw soil on it and knock it down to maintain spring quality (Anvari, 2003). From the outside view, Zurkhaneh is shaped cubic and often has a dome over it. The dimensions of the Zurkhaneh are like a small temple, which can only accommodate a small group.

Because of the short entrance door of the Zurkhaneh, every person should take a bow at the threshold of the Zurkhaneh, and this is the best way to salute others without any words, and thus, Zurkhaneh has the power and humility at the same time. On the other hand, the short entrance is one of the oldest protection methods, as it bans the enemy to move into space (Amini, 2012). Along the entrance to the Zurkhaneh, just like temples mithtra, there's a fountain, which today has lost its original use. Instead of the fireplaces that were located in the sanctuary at the end of the temple, fireplace is used in the Zurkhaneh is used today to heat and make hot drinks (Saykhon, 2011). The place of fire in Zurkhaneh is called "Sardam" and is used to provide a sitting place for the leader of Zurkhaneh. Sardam, it is located at a distance of one meter to the entrance and is a wooden or masonry pedestal. It's a place for the coach to sing and beat the marsh, and in front of it is a hanging bell. (Bois, 1381). The coach rings the bell and calls upon the arrival of the athletes. In the temples of Mithra, there is also a bell that they ring to call it when showing the image of the Mithra at the end or the beginning of the ceremony, or maybe they ring the bell when the priests enter (Aghajani, 2012).

The current style of the Zurkhaneh is more similar to the monasteries of Sufism than a sport site (Poor Davood, 2005). The shape of the Zurkhaneh is reliance on the monasteries and monasteries look like the ancient Iranian temples (Anwari, 2003). The shape of the altar made in Zurkhaneh is probably influenced by Islamic mosques, it can be claimed that it has 
been influenced by the form of the Mithraist temples more than the mosque's altar, which usually has a dome which is ornamented by the stars, and on both sides there are platforms for sitting (Bowys, 2002). However, the shape of the monastery and the Zurkhaneh are very similar in appearance and in the manner. However, even if pre-Islamic Zurkhaneh was influenced by the symbols of the Mithraist temple, they are similar to the monastery of the Sufis, and this cannot be ignored.

Facade and outer and inner shape of the Zurkhaneh is similar to the Sufist monasteries. After the advent of Islam, Zurkhaneh and monastery were the center of the Sufism and the reference of the pilgrims and the followers of the Prophet Mohammad. Both monastery and Zurkhaneh are placed at lower surface of the earth, and have the threshold of short entry. One of the reasons for lowering the Zurkhaneh is that athletes become down to earth as possible (Anasory, 2004).

The scene of Zurkhaneh is octagonal and its length is from 8 to 12 inches, and can contain 20 exercising athletes. Around it is usually four rooms, like the old baths. The roof of the Zurkhaneh is circular and up to 10 meters (Aghajani, 2012).

Table 1 - Plans of Zurkhaneh

No.
Tayyeb Zurkhaneh;
Khorram Abad




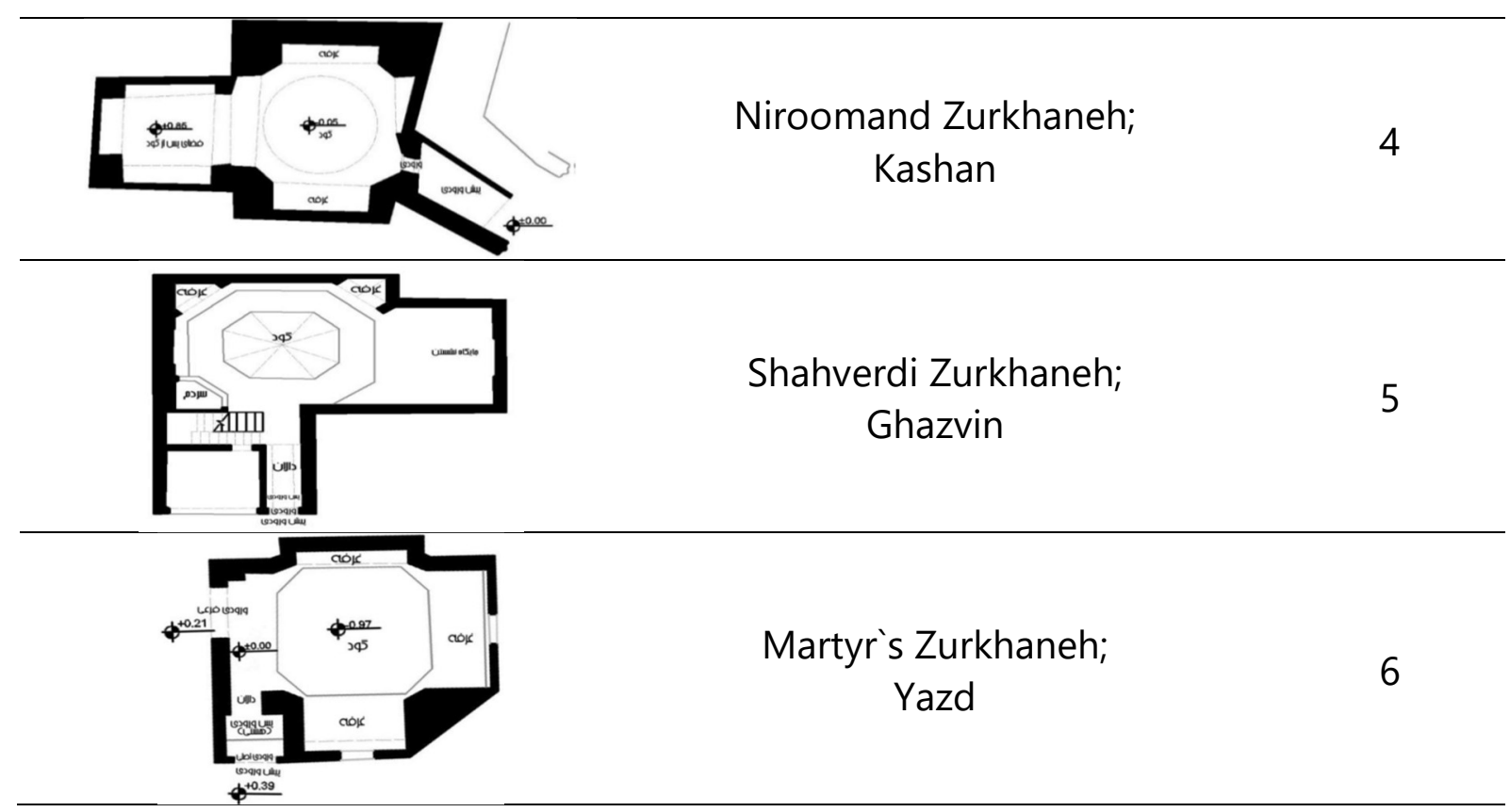

\section{One; The Holy Number}

Imam Ali is the most important Hero of the Athletes. After Islam, anti-demon features among the ancient Iranians turned into Islamic belief and appeared in a ritual that was called the "ritual of Generosity". The followers of the ritual, along with the goodness of the Imam Ali, were always salute to Ali and his family, curse their enemies. The same tradition is still common in Zurkhaneh today (Hodgson, 1999).

"The crown of poverty", is the highest degree in Zurkhaneh: As there are various stages in the Sufism and the highest level is poverty, which is the symbol of getting rid of all the earthly things and reaching to a heavenly degree, if an athlete reaches the highest level of physical strengthen wears the crown of poverty (Purdavood, 2005). he ties his knees, meaning he would never kneel in the fight.

"Taking the Stone" which is one of the games that played in Zurkhaneh is a remembrance of Imam Ali. Today, the two stones are made of wood. Each stone is 20 to 40 kilograms. Some of its history has been attributed to the removal of the doors of castle Khaybar by the hands of Imam Ali. Those two stones are the symbol of that door. (Anvari, 1382). 
Most of the architectural elements in Zurkhaneh are unique, including the entrance, the scene, and Sardam. Meanwhile, because of the placement of the coach, Sardam has a special status (Anvari, 2003). Sardam is a place on which the coach sits, The Coach acts like a marshal, and the athletes are the warriors who fight with their devilish soul and build their bodies against the oppressed and the powerful enemy. As a result, athletes follow the marshal like an Imam. They placed the image of Imam Ali at the top of Sardam (Aghajani, 2002). In the outer view of Zurkhaneh, the dome, which is a symbol of unity, was built. Number one is the symbol of God (Anvari, 1382).

\section{Two; The Holy Number}

Binary of the good and evil has roots in Iranian culture, the good and evil dual are the eternal battle and good human beings are obliged to accompany good and avoid evil. The athletes are good and the poetry and words of the Zurkhaneh coach also point to the emphasis on goodness, and the good attributes are gradually institutionalized in athletes (Aghajani, 2002). Sardam is a reminder of the two principles of good thoughts and good words, because the good poetry and good words of the Coach relate the motto of good speech in mind. Followers of the ritual of Zurkhaneh First Imam of the Shiites, Ali, as their hero (Ghaderi , 2003).

The deeper meaning of wrestling is a struggle between good and evil inside the soul of a person. The concept of wrestling was a form of struggle between the trait and the accompanying ethics, even in Ancient Iran; it was also a kind of help For Ahura Mazda, the ancient God of good against Ahriman the God of evil (Hodgson, 1999).

The scene of Zurkhaneh is the symbol of the battle against the good and evil. Because the scene in the post-Islamic history is a hint of the pit of Imam Hussein's death in the desert of Karbala, and the athlete in the scene always sees himself in a dispute between right and wrong and is ready for a holy war (Anvari, 2003). 


\section{Six; The Holy Number}

There are "Six Principles of Purity" in Zurkhaneh. Humor is one of the most important principles of generosity. So the clothes of an athlete are sacred, because an athlete never takes off his clothes for adultery. So when an athlete enters the Zurkhaneh, he should keep three things "closed", and Three things "open: what is closed: his strap, his eyes off the women, and his tongue of bad words (Ansari, 1989).

The Scene is the central part of the Zurkhaneh, the octagonal or hexagonal pit, which is the main venue for the exercise. It is located about 1 meter below the ground, so that the athletes are placed at a lower level and may not feel proud at all (Fig. 1). After Islam, the scene became the symbol of Imam Hussein's death pit in the desert of Karbala. Athlete in the scene always sees himself in a dispute between right and wrong and prepared for Jihad, just like the way Imam Hussein did. (Anvari, 2003). The scene is also inspired by the hexagonal grave of Imam Hussein. (Ansari, 1989).

Fig 1 - Drawing of a Persian golden rectangle through a circular hexagon

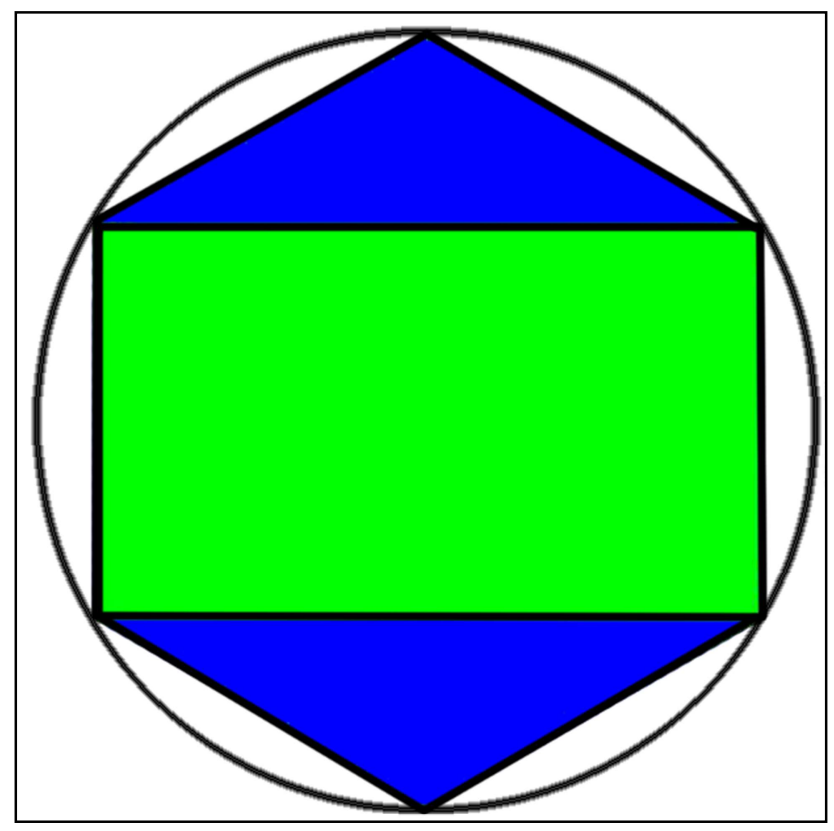

But the hexagonal has played a very important role in the architecture of Iran during the Islamic era. Pirnaya considers the radical 3 proportion, as an Iranian golden ratio that 
comes from a hexagonal, and believes that Iranian architecture is based on this fit. Since the hexagon drawing is created by dividing the circle by its radius, it is possible to draw it with the least possible instruments (Pirnia, 2008). Almost every Iranian building has used that golden rectangle form a courtyard, porch, room, etc...

\section{Eight; The holy number}

The athletes should have eight moral qualities, among them four special attributes is necessary: modesty, tranquility, truthfulness, and faithfulness. Holy prophet of Islam says: "Heaven has a big dome of pearl above, standing on the four walls, and on every wall the four divine letters are written". According to the Islamic traditions, the number eight refers to the eight angles that take the weight of the sky on their shoulders (Reza Shateryan, 2011).

The other name of the sun in the Pahlavi language is Mithra and the octagon is the symbol of mithra. The octagonal building under the dome, is the symbol of Heaven's throne. The square of under the dome is the symbol of the cosmic world on earth (Reza Shateryan, 2001).

The Scene is often octagonal, on the other hand, Imam Sadiq, the sixth Shiite imam, says: "Paradise has eight doors to enter." Thus, the octagonal scene, reminds the eight doors of paradise and the symbol of the eighth Imam of the Shiites.

\section{Twelve; The holy number}

Wearing the crown of generosity by an athlete, takes many ceremonies. Twelve words were called upon him, and then came the name of the twelve Imams. This was carried out by the hands of the Coach. In many words and issues of Zurkhaneh there is a number twelve which, reminded the twelve Shiite Imam (Hodgson, 1999).

While the Coach wants an athlete to get ready for the battle, he asks him to do twelve thing: ask god for forgiveness, say the prayer always on time, get away of hatred and jealousy, do not betray your brothers, be fare and don't forget about justice, not to be an oppressor, always be a disciple, fulfill others dreams, stay charitable, keep the honor of your 
kind, respect the human being, do not do cheap deeds (Waez Kashefi, 1969). There are also twelve things to do before wrestling, twelve things to do for the disciples, twelve things to do for the athletes (Hodgson, 1999).

In the pursuit of twelve Shiite Imams and expressing their faith in them, the number twelve in the Zurkhaneh architecture was the architect's concern. The length and width of the Zurkhaneh were designed twelve meters in twelve meters, and the altar was made of marble, which was of four meters lengths and a width of three meters, the product of which is twelve (Heidary and Dolatshah, 2012) .

Table 2 - The relation between Numbers, Belief, and Architecture

\begin{tabular}{lcc}
\hline \multicolumn{1}{c}{ Architecture } & Belief & Numbers \\
\hline $\begin{array}{l}\text { The Dome } \\
\text { The Scene }\end{array}$ & Imam Ali & 1 \\
\hline The Scene & The Good And The Evil Binary & 2 \\
\hline The Scene & Six Principles Of Purity & 6 \\
\hline $\begin{array}{l}\text { The Scene } \\
\text { The Dome }\end{array}$ & Eight Qualities Of Perfection & 8 \\
\hline $\begin{array}{l}\text { Dimensions } \\
\text { Zurkhaneh }\end{array}$ & Of & $\begin{array}{c}\text { Twelve Imams, } \\
\text { Twelve Principles }\end{array}$ \\
\hline
\end{tabular}

\section{Conclusion}

The root of the rituals and beliefs of Zurkhaneh sport is returned to the era of Mithraism. When the symbols were the best language to speak to the believers. Sacred temples were built in the form of caves and were connected with natural elements such as water. Even though Zurkhaneh was also built inside the city or near the Bazaar, but like the temples of Mithra, it was built with a few steps under the surface of the ground, and the only light source was the windows at the neck of the dome.

With the advent of Islam and the spread of Sufism, and the deep believe in the First Imam of Shiites, Ali, by the Sufist, athletes called themselves the disciples of Ali, and in the 
thought and practice followed him. The expansion of Shiism also changed the symbols and elements of Zurkhaneh, The symbol of the hexagonal grave of the Third Imam of the Shiites, Hussein, or the symbol of the eight gates of Paradise and the eighth Imam, Reza, was the octagon neck of the dome. Even the form and manner of holding ceremonies and Zurkhaneh sports, the numbers that have long been Sacred for people of Iran have also found a new symbolic role in architecture and sports of Zurkhaneh and became the manifestation of the mental beliefs of the followers and athletes in the sport and architecture of Zurkhaneh. By this means the connection between beliefs, rites, sports exercises and the architecture of Zurkhaneh has created a small and less-pretense building that is built in the heart of the city and Bazaar.

\section{References}

AGHAJANI, HOSSEIN, 2002, "Investigation of anthropology of Zurkhaneh in Kerman" , Danesh boomi Mag. Kerman.

AMINI, 2002, "designing the place and space in historical Dramas" Honarhaye Ziba Mag. , No 1, Tehran.

ANASORI, JABER; "The impact of Shiite ism on buildings" ; Shia Shenasi Publications. Tehran

ANSARI, KHAJEH ABDULLAH, " 100 Arenas" 1989, Translated by Ansari, Ghasem, Tahoori Publications, Tehran.

ANVARI, HASSAN, 2003; ' Culture of speech", Sokhan Publications, Tehran

BAHAR, MEHRDAD, 1972, " Mithraism and Ancient sports of Iran" , Farhang Zendegi mag, Tehran, Tehran

BAHAR, MEHRDAD, 1994, " Investigations In Iranian Culture" , Fekre Rooz Publications, Tehran

BEIZAI KASHANI, Parto, 2003, "The History of Zurkhaneh sports" , Tehran, Zavvar Publications

BOWIS, MERRY, 2002, " The Zoroastrians" , Translated By bahrami, Asgar, Ghoghnoos Publications, Tehran

BURKHARDT, TITUS, 2011, " Sacred Art" translated by Sattari, Jalal, Sorous Publications, 
Tehran

CHRITIAN ST, ARTHOR, 1980; "Iran in Sassanid era"; Translated by Rashid, Gholamreza; Ghesse Pardaz Publication.

CHRTIER, PAUL, 2009 " Sports, Music, and Zurkhaneh" „International congress of History and Culture of Zurkhaneh, Tehran

DADVAR, ABOLGHASEM, 2006; " An Introduction to symbols and Myth in Iran and India" Tehran, Alzahra University Publications

DOWLATSHAH, NASSER; HEIDARI , ALI; 2012, " Sufism, Generosity, Islam, and Zurkhaneh in Iran", Modiriat Varzeshi Magazine, Tehran

DUMPIER, WILLIAM; " The History of Science" , Translated by Azarang, Abdolhussein; S.A.M.T. Publications. 2007, Tehran

ENSAFPOOR, GHASEM, 1974, " History and Culture of Zurkhaneh", Ministry of arts and culture, Tehran.

GHADERI, 2003, "50 chapter of 6 th Religious discourse" ; Farhangestan publication, No 21 HODGSON,MARSHAL, 1999, "Ismayeele Cult", Translated by Badrei, Feraydoon, Elmi\& Farhangi publication, Tehran,

MEMARIAN, GHOLAM-HUSSEIN, "Iranian Architecture", Sorush Danesh" publication, Tehran.

MOHABBATI, MEHDI; " The King Book of Kings \& the identity crisis in Iran", Tehran; Jahad Daneshgahi publication

MOKHTARI, IBRAHIM; 2002; "Athletic Heritage" ; Tehran; Entesharat Va Tolidat Farhangi Publication

MOSTAFA ALSHAIBI, KAMEL; 1980, "Shiite ism \& Sufism" Translated by Zekavati, Alireza; AmirKabir Publication, Tehran

N. DEIMARY, M.MOHAMMADI. (2017). Investigating the Impact of Ancient and Heroic Rituals on Formation of Zurkhaneh Architecture in Iran. American International Journal of Research in Humanities, Arts and Social Sciences, 20(1), September-November, pp. 40-45

NAFISI, SAEED, 1998, "Roots of Sufism in Iran", Forughi Publication, Tehran.

PIRNIA, MUHAMMAD KARIM, 2009, " Islamic architecture of Iran; Sorush Danish Publications, Tehran

POURDAVOOD, EBRAHIM; 2005, "The Avesta", Donyaye Ketab Publication, Tehran

SAJJADI, ALI; 2001, " Tayyeb Zurkhaneh"; Ministry of Heritage and Handicrafts Publications, 
Khorram Abad;

SAYKHON, SANJIT SING; 2002; " How to expand Zurkhaneh sports abroad,

SEDDIGH, MOSTAFA 1964; " Zurkhaneh and ancient sport" , Honar-o-Mardom mag, No. 26

SEDDIGH, MOSTAFA; 1974; " The Creation of Zurkhaneh", Honar-o-Mardom mag, No. 145 SEDIGH IMANI, MOSTAFA; 1998, " Ritual of generosity in Zurkhaneh, through history" ; Ketabe mahe Honar Publications

SHATERIAN, REZA, 2011; " Architecture of Mosques in Iran" ; Nopardazan Publications, Tehran

VAEZ KASHEFI, MOLLA HUSSEIN, 1969, "Royal Biography", Translated by Mahjub, Muhammad Jafar, Iranian Culture Foundation, Tehran.

VAZIRI, ALI NAGHI, 2004, "General History of Visual Arts", Edition \& Print Publication, Tehran.

YAZDI, HASSAN, 2001, "Generosity, Heroic, Bravery, Championship and sports in Safavid era", Sports Management magazine, No. 10

ZARRINKOOB, ABDOLHUSSEIN, 1984, "A research in Sufism" Tehran, Amirkabir Publications

ZARRINKOOB, ABDOLHUSSEIN, 1990, " Oceans in a pot" Tehran, Elmi Publications 